\title{
A Welcome Addition
}

A SMALL but valuable lot of bank reports makes a noteworthy addition to the library of the Business Historical Society. These are charters and reports of some of the early Southern banks, and a number of the pamphlets relate to the culmination of the famous contest between Jackson and the second United States Bank. Among them is the veto with which the sturdy soldier and idol of of the populace, who was distrustful of all banks because he had once read about the South Sea Bubble, dealt the ill-fated institution its death blow. As our readers are aware, the document characteristically appeals to the agricultural West, the common man, and the hundred-per-cent American against what its opponents were wont to designate as the monstrous creature of Marquisses, Earls, and a few rich and privileged Easterners, the Bank. This, together with speeches of Webster, Clay, and John Quincy Adams on the one hand, and Senators Benton of Missouri and Hill of New Hampshire on the other, on the continuance of the charter, and the removal of the United States deposits, illustrates beautifully the character of the arguments used by both sides in this struggle, the issue of which was so surely foreordained. Was it any wonder that the people turned a deaf ear to the clear and sound reasoning of Webster, Clay and Adams, when they were being told by Benton, Hill and, above all, their great mouthpiece, Jackson, just what they had thought all the time, that a great monopoly like the Bank could but make the rich richer, and the poor poorer, and that it was being swallowed up by foreign stockholders, largely British, who would use it for the benefit of England in case of war?

With these historic documents, and the Southern material, this collection is a much needed addition to the array of bank reports available to the Society.

\section{Jn flemoriam}

THE Society has again been unfortunate in losing two of its members, Mr. George Woodbridge, one of the founders, and Mr. Russell Robb.

IN George Woodbridge, the Society loses one of its chief friends and supporters.. He died on February 16, 1927, at the Deaconess Hospital in Boston. He was one of the organizers, and a trustee of the 
Society, a man of wide and vivid interests, and untiring energy. He was born at the Watertown Arsenal, Massachusetts, the son of a distinguished officer in the Ordnance Department of the United States Army. As a young man he went into newspaper work, and was with the Boston Globe and the old Boston Fournal. At the time of his death he was at the head of George Woodbridge's Business Relations, and had been for several years a lecturer at the Harvard Business School, on the subjects of sales management, business policy, and insurance. He did much for Harvard University, and for the Business School in particular, being associated with Bishop Lawrence in the first Harvard endowment fund campaign, and among the inaugurators of the Bishop's campaign to extend the national service of Harvard University, which led to the gift of $\$ 5,000, \infty 00$ for the Business School, one of $\$ 3,000,000$ for the Department of Chemistry, and of $\$ 2,000,000$ for the Department of Fine Arts. He was not only instrumental in founding The Business Historical Society, but because of his vivid imagination, his comradeship, his spirit of helpful coöperation, the Society has lived and prospered over the initial period of foundation and growth. His death at the early age of fifty-three is a severe blow to our Society and a personal loss to each and every member.

Russell Robb, nationally known engineer and senior vice-president and treasurer of Stone and Webster, Inc. of Boston, died February 15, 1927, after a short illness. Mr. Robb was born in Dubuque, Iowa; he graduated from Technology in 1888 . A year later, he entered his life work with the Thomson Electric Welding Company, and was with them until I 891 , when he entered the employ of Stone and Webster. There he rapidly made a reputation for himself as an executive in every branch of engineering. He was vice-president of his firm from 1905 until his death. $\mathrm{He}$ was a director of, or interested in, many traction, light and power companies, and a member of many clubs. He was also an author, and wrote numerous magazine articles and books. His treatise on "Business Organization" is used as a textbook at the Harvard Business School, where he often lectured. He was a generous contributor to the Business Historical Society and a supporter of the Harvard Business School. His family home was in Concord. He died at Phillips House in Boston, at the age of sixty-three. 